\title{
Natural canine infection by Leishmania infantum and Leishmania amazonensis and their implications for disease control
}

\author{
Infecção natural por Leishmania infantum e Leishmania amazonensis e suas implicaçôes \\ para o controle da doença
}

Letícia da Cruz Sanches ${ }^{1}$; Cleber Costa de Martini'; Alex Akira Nakamura ${ }^{1}$; Maria Emília Bodini Santiago²; Beatriz Dolabela de Lima ${ }^{3}$; Valéria Marçal Felix de Lima ${ }^{1 *}$

\author{
${ }^{1}$ Departamento de Clínica, Cirurgia e Reprodução Animal, Faculdade de Medicina Veterinária de Araçatuba, Universidade Estadual \\ Paulista - UNESP, Araçatuba, SP, Brasil \\ ${ }^{2}$ Zoológico Municipal de Bauru, Bauru, SP, Brasil \\ ${ }^{3}$ Departamento de Biologia Celular, Instituto de Ciências Biológicas, Universidade de Brasília - UnB, Brasília, DF, Brasil
}

Received August 24, 2016

Accepted September 21, 2016

\begin{abstract}
Leishmaniasis is a major public health problem worldwide. Because Leishmania can adapt to new hosts or vectors, knowledge concerning the current etiological agent in dogs is important in endemic areas. This study aimed to identify the Leishmania species detected in 103 samples of peripheral blood from dogs that were naturally infected with these protozoa. The diagnosis of leishmaniasis was determined through parasitological examination, the indirect enzyme-linked immunosorbent assay (ELISA) and the polymerase chain reaction (PCR). The Leishmania species were identified by means of PCR-restriction fragment length polymorphism (PCR-RFLP). The samples were subjected to PCR using oligonucleotide primers that amplify the intergenic region ITS1 of the rRNA gene in order to identify the species. The amplified DNA was digested using the restriction enzyme HaeIII. A restriction profile identical to L. amazonensis was shown in 77/103 samples and the profile was similar to L. infantum in 17/103. However, a mixed profile was shown in $9 / 103$ samples, which impeded species identification. In conclusion, the infection in these dogs was predominantly due to $L$. amazonensis, thus indicating that diagnosing of cases of canine leishmaniasis needs to be reexamined, since the causative agent identified is not restricted to $L$. infantum.
\end{abstract}

Keywords: Canine, Leishmania spp., leishmaniasis, zoonosis.

\section{Resumo}

Leishmaniose é um grande problema de saúde pública global. Devido à adaptação de Leishmania a novos hospedeiros ou vetores, conhecimentos sobre o agente etiológico atual em cáes é importante em áreas endêmicas. Este estudo teve como objetivo identificar as espécies de Leishmania detectadas em 103 amostras de sangue periférico de cáes naturalmente infectados com este protozoário. O diagnóstico de leishmaniose foi determinado por exame parasitológico, ensaio imunoenzimático (ELISA) e a reação em cadeia da polimerase (PCR). A identificação das espécies de Leishmania foi realizada por PCR - seguido da análise do polimorfismo no comprimento de fragmentos de restriçáo (PCR-RFLP). As amostras foram submetidas a PCR utilizando-se iniciadores oligonucleotídicos que amplificam a região intergénica ITS1 do gene de rRNA para identificar as espécies, o DNA amplificado foi digerido com a enzima de restrição HaeIII. Observou-se que 77/103 amostras mostraram um perfil de restrição idênticos a L. amazonensis, 17/103 foram semelhantes para L. infantum; 09/103 mostraram um perfil misto, o que impediu a identificação da espécie. Em conclusão, a infecção nestes cáes era predominantemente devido a $L$. amazonensis, indicando que o diagnóstico de casos de leishmaniose canina precisa ser reexaminada, já que o agente causador não está restrito a $L$. infantum.

Palavras-chave: Canino, Leishmania spp., leishmaniose, zoonoses.

*Corresponding author: Valéria Marçal Felix de Lima. Departamento de Clínica, Cirurgia e Reprodução Animal, Faculdade de Medicina Veterinária de Araçatuba, Universidade Estadual Paulista - UNESP, Rua Clovis Pestana, 793, CEP 16050-400, Araçatuba, SP, Brasil. e-mail: vmflima.fmva.unesp.br 


\section{Introduction}

Leishmaniasis is one of the principal global public health problems. Protozoa of the genus Leishmania are distributed worldwide and the epidemiology of the leishmaniasis depends on the characteristics of the species involved (WHO, 2013). Their geographical distribution is limited by vector distribution and, over recent years, the number of cases has continually increased (WHO, 2013).

Leishmaniasis is a disease characterized by damage to the skin, mucosa and viscera, according to the species of Leishmania and the host immune response. The disease can be caused by over 30 species of Leishmania and transmission occurs through the bits of sandflies of the genera Phlebotomus and Sergentomyia in the Old World and Lutzomyia in the New World (BATES, 2007), although other possible vectors (COUTINHO et al., 2005; DANTAS-TORRES et al., 2010; FERREIRA et al., 2009) and transmission via blood transfusion have been reported (OWENS et al., 2001).

Visceral leishmaniasis (VL) can be fatal, mucocutaneous leishmaniasis causes mutilation and diffuse cutaneous leishmaniasis (CL) has a long disease course due to cellular immune deficiency. CL can be debilitating when the patient presents multiple lesions (ALVAR et al., 2004; DESJEUX, 2004).

VL mainly affects domestic dogs, which are the main reservoir of the parasite for humans (DANTAS-TORRES, 2007). There have also been reports of infection in cats (SOBRINO et al., 2008), wild canids (LIMA et al., 2009) and horses (DANTAS-TORRES, 2007). In CL transmission foci, dogs and other animals are not exposed as reservoirs but as accidental hosts, together with humans (DANTAS-TORRES, 2007).

Therefore, knowledge concerning the Leishmania species circulating in dogs in endemic areas is important. To diagnose the disease in dogs, the most commonly used methods are parasitological and/or serological tests, but these do not determine the species of the parasite (DEGRAVE et al., 1994).

Visceral leishmaniasis has spread out across the entire Brazil, with autochthonous cases reported in $25 \%$ of Brazilian municipalities in 21 states (WERNECK, 2014). The current strategies for the prevention and control of VL applied by the Brazilian Health Ministry include 1) early diagnosis and adequate treatment of human cases; 2) use of residual insecticides and sanitary measures targeting the home environment to reduce vector density; and 3) seroreactive dogs should be diagnosed and culled (BRASIL, 2006). On the other hand, there is no effective control measure for cases of CL.

The restriction fragment length polymorphism analysis of polymerase chain reaction amplified fragments (PCR-RFLP) detects and distinguishes between different species through amplification of polymorphic regions found in parasite RNA. The internal transcribed spacer (ITS1) region is located between the small and large gene unit of the RNA and constitutes a noncoding region that exhibits about 200 copies in the Leishmania genome. This region presents polymorphism, which permits differentiation among species of Leishmania, and this region is specifically amplified only in the genus Leishmania (DWEIK et al., 2007).
Over recent years, the city of Bauru, in the state of São Paulo, Brazil, has supported efforts to control outbreaks of VL in the city in both humans and dogs. Species identification is critical to development of control programs in each case. The technique that is used needs to assist in identifying the circulating strains of Leishmania in dogs.

The purpose of this study was to identify the Leishmania species detected in 103 samples of peripheral blood from dogs that were naturally infected with these protozoa in the city of Bauru, using PCR-RFLP.

\section{Materials and Methods}

\section{Study animals and clinical samples}

A total of 154 adult dogs of varying ages, breeds and sizes that were either asymptomatic or symptomatic for leishmaniasis were provided by the Bauru Zoonosis Control Center. Their parasitological diagnosis of the presence of Leishmania spp. had been confirmed through cytological examination of aspiration biopsies on lymph nodes. The dogs were put down by means of anesthesia with intravenous barbiturate (thiopental; Cristália Itapira), followed by intravenous injection of $19.1 \%$ potassium chloride. The procedure was performed in accordance with the recommendations of Resolution no. 714 of June 20, 2002, of the Federal Council of Veterinary Medicine, in compliance with Decree no. 51,838 of the Brazilian Ministry of Health of March 14, 1963, which states that pets infected with VL should be put down.

Immediately following this, $2 \mathrm{ml}$ of peripheral blood were collected by means of jugular vein puncture and were stored in tubes containing EDTA. One milliliter was used for DNA extraction and the remainder was centrifuged at $3000 \mathrm{rpm}$ for $15 \mathrm{~min}$ at $4{ }^{\circ} \mathrm{C}$ in order to obtain plasma for detection of anti-Leishmania antibodies through the enzyme-linked immunosorbent assay (ELISA). The crude Leishmania infantum antigen preparation and the ELISA procedure were performed as previously described by (LIMA et al., 2003). This study was approved by the Research Ethics and Animal Experimentation Committee of the Araçatuba School of Veterinary Medicine of São Paulo State University (FMVA/UNESP), under protocol no. 002232.

\section{DNA extraction from blood samples}

DNA extraction from peripheral blood samples from the dogs was performed using the DNAeasy ${ }^{\circledR}$ commercial kit (Qiagen, Valencia, California, 91355, USA), following the manufacturer's recommendations. The DNA was quantified using a spectrophotometer at 260/280 nm (NanoDrop Technologies ND 1000 UV/VIS, USA), to evaluate the degree of purity, and was then stored at $-20{ }^{\circ} \mathrm{C}$.

\section{Polymerase chain reaction}

Determination of the Leishmania species was performed by means of PCR-RFLP. The initial step involved PCR with primers that amplified the intergenic region ITS1 of the rRNA gene (5' AGCTGGATCATTTTCCGATG 3', 5' TATGTGAGCCGTTATCCACGC 3'). 
The PCR reaction was performed with $100 \mathrm{ng}$ of purified DNA, $12.5 \mu \mathrm{l}$ of JumpStart Taq ReadyMix $(20 \mathrm{mM}$ of Tris- $\mathrm{HCl}$ at $\mathrm{pH}$ $8.3,100 \mathrm{mM}$ of $\mathrm{KCl}, 3 \mathrm{mM}$ of $\mathrm{MgCl}_{2}, 0.4 \mathrm{mM}$ of each dNTP dATP, dCTP, dGTP, dTTP, $0.1 \mathrm{U} / \mu$ l of Taq DNA polymerase and JumpStart Taq antibody) (JumpStart ${ }^{\mathrm{TM}} \mathrm{Taq}^{\mathrm{ReadyMix}}{ }^{\mathrm{TM}}$, Sigma-Aldrich ${ }^{\circledR}$ Inc., St. Louis, MI 63103, USA), 10 pmol of each oligonucleotide primer and $6.5 \mu \mathrm{l}$ of ultrapure water, in a final reaction volume of $25 \mu \mathrm{l}$.

PCR was performed under the following conditions: an initial denaturation cycle at $94^{\circ} \mathrm{C}$ for $60 \mathrm{~s}$, followed by 35 cycles of denaturation at $94^{\circ} \mathrm{C}$ for $30 \mathrm{~s}$, primer annealing at $56^{\circ} \mathrm{C}$ for $30 \mathrm{~s}$ and extension at $72{ }^{\circ} \mathrm{C}$ for $40 \mathrm{~s}$.

The amplified fragments were viewed using a transilluminator on $2 \%$ agarose gel stained with ethidium bromide. Samples were considered positive when an amplified fragment of 227-268 bp was detected. For Leishmania species identification, the amplified DNA was then digested with the restriction enzyme HaeIII: $2 \mathrm{U}$ for $1 \mathrm{~h}$ at $37^{\circ} \mathrm{C}$ (Restriction Endonuclease HaeIII; Sigma-Aldrich ${ }^{\circledR}$ Inc., USA). The digested product was then viewed using a transilluminator on $2 \%$ agarose gel stained with ethidium bromide, and was documented on $10 \%$ polyacrylamide gels stained with red gel (Uniscience Ltd., Cambridge, UK). The restriction profile of the sample was compared with the standard PCR restriction product obtained when using the species $L$. infantum (IOC/L2906-MHOM/BR/2002/LPC-RPV), L. braziliensis (IOC/L0566- MHOM/BR/1975/M2903) and L. amazonensis (IOC/L0575-MHOM/BR/1967/PH8) as positive controls and water as the negative control, thus enabling identification of the species of Leishmania. A 100 bp molecular weight marker was used (Invitrogen, Carlsbad, CA 92008, USA).

\section{Results}

\section{Indirect ELISA and PCR}

All the plasma samples $(\mathrm{n}=154)$ were subjected to indirect ELISA to detect anti-Leishmania antibodies. Among these, 76.6\% $(\mathrm{n}=118)$ showed positive results. However, PCR confirmed infection in only $87.3 \%(n=103)$ of the samples that were positive according to indirect ELISA.

\section{PCR-RFLP}

The samples positive for ELISA and PCR were subjected to PCR-RFLP and the profile of the restriction fragments indicated that $74.8 \%(\mathrm{n}=77)$ of the samples were infected by $L$. amazonensis, $16.5 \%(\mathrm{n}=17)$ by $L$. infantum and the remaining samples $(8.7 \% ; n=9)$ exhibited a mixed profile, in which two fragments of less than 100 bp that were identical to L. infantum and two fragments of more than 100 bp that were identical to L. amazonensis were observed. Thus, for these specimens, species identification using this technique was not possible. A representative polyacrylamide gel showing PCR-RFLP is shown in Figure 1.

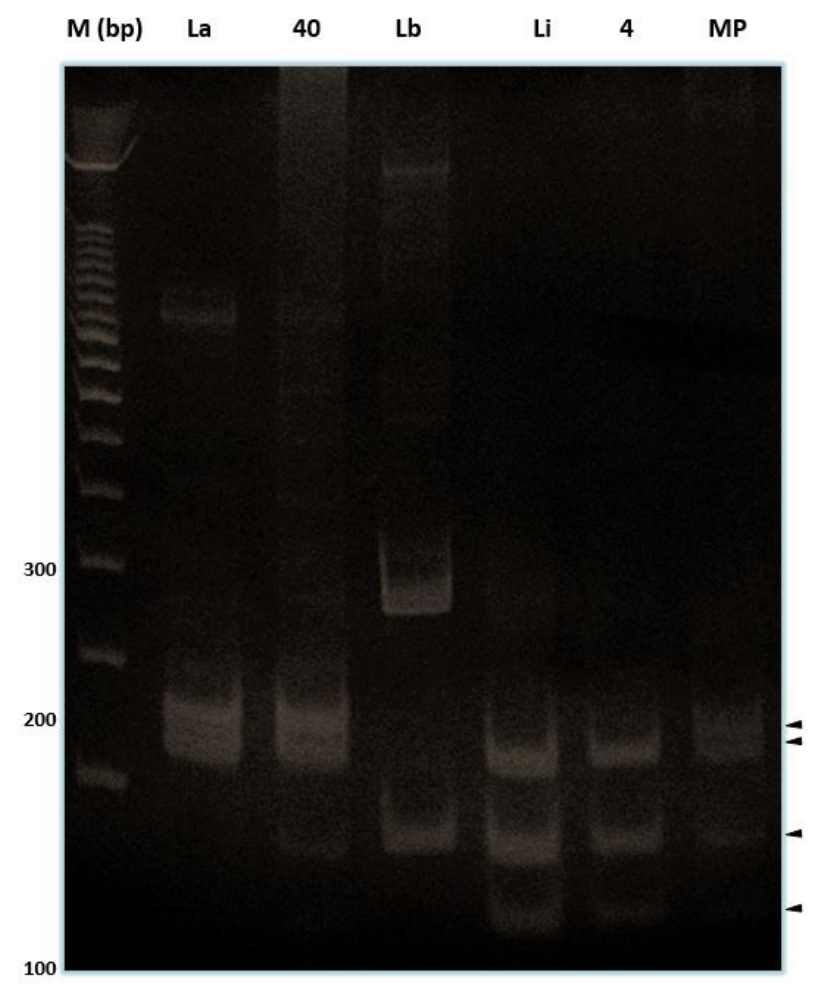

Figure 1. Restriction fragment length polymorphism (RFLP) analysis of ITS1-PCR fragments amplified from samples and standard isolates DNA, by using Hae III. M: molecular marker (100 bp); La: Leishmania amazonensis; 40: sample profile identical to Leishmania amazonensis; Lb: Leishmania braziliensis; Li: Leishmania infantum; 4: sample profile identical to Leishmania infantum; MP: samples with xed profile. Restriction fragment length polymorphisms (RFLP) were documented on $10 \%$ polyacrylamide gels stained with red gel. The restriction fragment length polymorphism (RFLP) are indicated by arrow.

\section{Discussion}

This study was conducted to characterize Leishmania species in dogs in the city of Bauru, SP, Brazil. We observed that the species L. amazonensis predominated $(74.8 \%)$ in the peripheral blood samples from the dogs evaluated in this city.

The high frequency of infection caused by L. amazonensis $(74.8 \%)$ seen in the dogs in this study showed that the disease that is treated in many cases as canine VL (caused by L. infantum) is in fact infection by L. amazonensis, which causes the cutaneous form of the disease. It also highlights the affirmation that serological diagnoses cannot differentiate visceral from cutaneous infection (TOLEZANO et al., 2007). The Brazilian leishmaniasis control program recommends that seroreactive dogs should be diagnosed and culled as a control measure for VL, and although there is no effective control measure for cases of CL, the program also suggests that the parasite species may be identifiable in areas of transition or simultaneous occurrence of CL and VL. Parasite species identification needs to be mandatory, so as to avoid unnecessarily putting dogs down. Therefore, leishmaniasis control programs should not be based solely on serological tests, because the technique that has been used does not enable species identification. 
Given the high frequency of $L$. amazonensis observed in dogs, these occurrences could be contributing towards increasing numbers of human cases of CL in large cities like Bauru and in adjacent cities (CVE, 2004). Although infection by L. amazonensis in humans is not considered common, it has been identified in the Northeast, Southeast, South and Center-West regions of Brazil (ASHFORD, 2000; DORVAL et al., 2006; GRIMALDI et al., 1989; GRISARD et al., 2000; LAINSON, 1985; LAINSON \& SHAW, 1987; PASSOS et al., 1999).

Despite wide distribution of leishmaniasis in the state of São Paulo, little is known concerning its clinical and epidemiological features. However, it is known that the distribution of Leishmania species is subject to the presence of vectors and/or their reservoirs. Moreover, infection in humans depends on their relationship with the chain of parasite transmission (ASHFORD, 2000; LAINSON, 1985). The latest surveys of phlebotomine fauna conducted in some areas of São Paulo have determined that Lutzomyia intermedia is the most abundant species in this state (SHIMABUKURO \& GALATI, 2011; SILVA et al., 2012), which coincides with findings of infection by L. (V.) braziliensis (CAMARGO-NEVES et al., 2002). In contrast, L. flaviscutellata, the vector species of $L$. (L.) amazonensis, has not been found. Thus, it seems reasonably likely that $L$. amazonensis has adapted to different vectors, as previously reported for L. braziliensis (ODDONE, 2007), because of the high number of dogs infected with Leishmania amazonensis.

The high positivity for L. amazonensis seen in the samples from dogs in Bauru may have resulted from interaction between dogs that present the vector and wild animal carriers of $L$. amazonensis. The species L. amazonensis has been detected in spider monkeys in Bauru zoo (LIMA et al., 2012).

In the past, São Paulo State had many cases of cutaneous leishmaniasis (VALE \& FURTADO, 2005). More recently, there was an outbreak of visceral leishmaniasis, so it is reasonable to assume that some of the dogs involved actually had cutaneous disease, as observed in our results. Little attention has been paid to species determination in the area studied, such that previously, only Leishmania spp. was detected (TRONCARELLI et al., 2009).

Similarly to our study, cutaneous infection has also been reported in Araçatuba, SP, Brazil, an area that is endemic for VL in peridomestic areas. The resulting infection presented symptoms similar to VL caused by L. infantum. Among the 13 samples that were found to be positive through PCR in the study conducted in Araçatuba, the causative agent in two cases of CL was identified as L. amazonensis, even though these presented clinical signs of $\mathrm{VL}$ (TOLEZANO et al., 2007).

\section{Conclusion}

Our data enabled identification of the species L. amazonensis and L. infantum in dogs in Bauru, SP, Brazil. These findings indicate that the diagnoses of cases of canine leishmaniasis need to be reexamined, since the causative agent identified is not restricted to L. infantum, which commonly causes visceral leishmaniasis, but may also include L. amazonensis, the Leishmania species that can cause the cutaneous form. In endemic areas, more than one etiological agent may be circulating, and therefore there is a need to identify the parasite species, so as to guide leishmaniasis control programs.

\section{Conflict of Interest Statement}

None of the authors has any financial or personal relationships that could have inappropriately influenced or biased the content of the paper.

\section{References}

Alvar J, Cañavate C, Molina R, Moreno J, Nieto J. Canine leishmaniasis. Adv Parasitol 2004; 57: 1-88. PMid:15504537. http://dx.doi.org/10.1016/ S0065-308X(04)57001-X.

Ashford RW. The leishmaniases as emerging and reemerging zoonoses. Int J Parasitol 2000; 30(12-13): 1269-1281. PMid:11113254. http:// dx.doi.org/10.1016/S0020-7519(00)00136-3.

Bates PA. Transmission of Leishmania metacyclic promastigotes by phlebotomine sand flies. Int J Parasitol 2007; 37(10): 1097-1106. PMid:17517415. http://dx.doi.org/10.1016/j.ijpara.2007.04.003.

Brasil. Ministério da Saúde. Departamento de Vigilância Epidemiológica, Secretaria de Vigilância em Saúde. Manual de vigilância e controle da Leishmaniose Visceral. Brasília; 2006. 122 p.

Camargo-Neves VLF, Gomes AC, Antunes JLF. Correlação da presença de espécies de flebotomíneos (Diptera: Psychodidae) com registros de casos da leishmaniose tegumentar americana no Estado de São Paulo, Brasil. Rev Soc Bras Med Trop 2002; 35(4): 299-306. PMid:12170323. http://dx.doi.org/10.1590/S0037-86822002000400004.

Centro de Vigilância Epidemiológica - CVE. Leishmaniose tegumentar americana [online]. São Paulo: Secretaria de Estado da Saúde; 2004 [cited 2016 Aug 24]. Available from: ftp://ftp.cve.saude.sp.gov.br/doc_tec/ ZOO/LTA_gve7ed_web_atual.pdf

Coutinho MT, Bueno LL, Sterzik A, Fujiwara RT, Botelho JR, De Maria M, et al. Participation of Rhipicephalus sanguineus (Acari: Ixodidae) in the epidemiology of canine visceral leishmaniasis. Vet Parasitol 2005; 128(1-2): 149-155. PMid:15725545. http://dx.doi.org/10.1016/j. vetpar.2004.11.011.

Dantas-Torres F, Lorusso V, Testini G, Paiva-Cavalcanti M, Figueredo LA, Stanneck D, et al. Detection of Leishmania infantum in Rhipicephalus sanguineus ticks from Brazil and Italy. Parasitol Res 2010; 106(4): $857-$ 860. PMid:20127362. http://dx.doi.org/10.1007/s00436-010-1722-4.

Dantas-Torres F. The role of dogs as reservoirs of Leishmania parasites, with emphasis on Leishmania (Leishmania) infantum and Leishmania (Viannia) braziliensis. Vet Parasitol 2007; 149(3-4): 139-146. PMid:17703890. http://dx.doi.org/10.1016/j.vetpar.2007.07.007.

Degrave W, Fernandes O, Campbell D, Bozza M, Lopes U. Use of molecular probes and PCR for detection and typing of Leishmania - mini review. Mem Inst Oswaldo Cruz 1994; 89(3): 463-469. PMid:7476234. http://dx.doi.org/10.1590/S0074-02761994000300032.

Desjeux P. Leishmaniasis: current situation and new perspectives. Comp Immunol Microbiol Infect Dis 2004; 27(5): 305-318. PMid:15225981. http://dx.doi.org/10.1016/j.cimid.2004.03.004.

Dorval MEMC, Oshiro ET, Cupollilo E, Castro ACC, Alves TP. Ocorrência de leishmaniose tegumentar americana no Estado do Mato Grosso do Sul associada à infecção por Leishmania (Leishmania) amazonensis. Rev Soc Bras Med Trop 2006; 39(1): 43-46. PMid:16501765. http://dx.doi. org/10.1590/S0037-86822006000100008. 
Dweik A, Schönian G, Mosleh IM, Karanis P. Evaluation of PCR-RFLP (based on ITS-1 and HaeIII) for the detection of Leishmania species, using Greek canine isolates and Jordanian clinical material. Ann Trop Med Parasitol 2007; 101(5): 399-407. PMid:17550645. http://dx.doi. org/10.1179/136485907X176436.

Ferreira MG, Fattori KR, Souza F, Lima VM. Potential role for dog fleas in the cycle of Leishmania spp. Vet Parasitol 2009; 165(1-2): 150-154. PMid:19595512. http://dx.doi.org/10.1016/j.vetpar.2009.06.026.

Grimaldi G Jr, Tesh RB, McMahon-Pratt D. A review of the geographic distribution and epidemiology of leishmaniasis in the new world. Am J Trop Med Hyg 1989; 41(6): 687-725. PMid:2701633.

Grisard EC, Steindel M, Shaw JJ, Ishikawa EAY, Carvalho-Pinto CJ, EgerMangrich I, et al. Characterization of Leishmania sp. strains isolated from autochthonous cases of human cutaneous leishmaniasis in Santa Catarina State, southern Brazil. Acta Trop 2000; 74(1): 89-93. PMid:10643912. http://dx.doi.org/10.1016/S0001-706X(99)00054-6.

Lainson R, Shaw JJ. Evolution, classification and geographical distribution. In: Peters W, Killick-Kendrick R. The leishmaniasis in biology and medicine. 1st ed. London: Academic Press; 1987. p. 1-120.

Lainson R. Our present knowledge of the ecology and control of leishmaniasis in the Amazon region of Brazil. Rev Soc Bras Med Trop 1985; 18(1): 47-56. http://dx.doi.org/10.1590/S0037-86821985000100011.

Lima VMF, Fattori KR, Michelin AF, Nogueira FS, Souza LO. Evidence of Leishmania spp. antibodies and DNA in bush dogs (Speothos venaticus) in Brazil. J Zoo Wildl Med 2009; 40(1): 91-94. PMid:19368245. http:// dx.doi.org/10.1638/2008-0043.1.

Lima VMF, Gonçalves ME, Ikeda FA, Luvizotto MCR, Feitosa MM. Anti-Leishmania antibodies in cerebrospinal fluid from dogs with visceral leishmaniasis. BrazJ Med Biol Res 2003; 36(4): 485-489. PMid:12700826. http://dx.doi.org/10.1590/S0100-879X2003000400010.

Lima VMF, Santiago MEB, Sanches LC, Lima BD. Molecular diagnosis of Leishmania amazonensis in a captive spider monkey in Bauru, São Paulo, Brazil. J Zoo Wildl Med 2012; 43(4): 943-945. PMid:23272368. http://dx.doi.org/10.1638/2012-0059R1.1.

Oddone R. Ecoepidemiology of american tegumentary leishmaniasis due to Leishmania braziliensis. In: Pan American Health Organization - PAHO. Update of American Trypanosomiasis and Leishmaniasis Control and Research: Final Report. Rio de Janeiro, Brazil; 2007. Washington: PAHO/WHO; 2007. p. 144-146.

Owens SD, Oakley DA, Marryott K, Hatchett W, Walton R, Nolan TJ, et al. Transmission of visceral leishmaniasis through blood transfusions from infected English foxhounds to anemic dogs. J Am Vet Med Assoc 2001; 219(8): 1076-1083. PMid:11700704. http://dx.doi.org/10.2460/ javma.2001.219.1076.

Passos VMA, Fernandes O, Lacerda PAF, Volpini AC, Gontijo CMF, Degrave W, et al. Leishmania (Viannia) braziliensis is the predominant species infecting patients with American cutaneous leishmaniasis in the State of Minas Gerais, Southeast Brazil. Acta Trop 1999; 72(3): 251-258. PMid:10232781. http://dx.doi.org/10.1016/S0001-706X(98)00100-4.

Shimabukuro PHF, Galati EAB. Lista de espécies de Phlebotominae (Diptera, Psychodidae) do Estado de São Paulo, Brasil, com comentários sobre sua distribuição geográfica. Biota Neotrop 2011; 11(S1): 685-704. http://dx.doi.org/10.1590/S1676-06032011000500033.

Silva RA, Mercado VTC, Henriques LF, Ciaravolo RMC, Wanderley DMV. Magnitude e tendência da leishmaniose tegumentar americana no Estado de São Paulo, Brasil, 1975 a 2008. Rev Bras Epidemiol 2012; 15(3): 617-626. PMid:23090308. http://dx.doi.org/10.1590/S1415790X2012000300015.

Sobrino R, Ferroglio E, Oleaga A, Romano A, Millan J, Revilla M, et al. Characterization of widespread canine leishmaniasis among wild carnivores from Spain. Vet Parasitol 2008; 155(3-4): 198-203. PMid:18579311. http://dx.doi.org/10.1016/j.vetpar.2008.05.003.

Tolezano JE, Uliana SR, Taniguchi HH, Araújo MF, Barbosa JA, Barbosa JE, et al. The first records of Leishmania (Leishmania) amazonensis in dogs (Canis familiaris) diagnosed clinically as having canine visceral leishmaniasis from Araçatuba County, São Paulo State, Brazil. Vet Parasitol 2007; 149(3-4): 280-284. PMid:17720321. http://dx.doi.org/10.1016/j. vetpar.2007.07.008.

Troncarelli MZ, Camargo JB, Machado JG, Lucheis SB, Langoni H. Leishmania spp. and/or Trypanosoma cruzi diagnosis in dogs from endemic and nonendemic areas for canine visceral leishmaniasis. Vet Parasitol 2009; 164(2-4): 118-123. PMid:19625128. http://dx.doi.org/10.1016/j. vetpar.2009.06.027.

Vale ESC, Furtado T. Leishmaniose tegumntar no Brasil: revisão histórica da origem, expansão e etiologia. An Bras Dermatol 2005; 80(4): 421-428. http://dx.doi.org/10.1590/S0365-05962005000400015.

Werneck GL. Visceral leishmaniasis in Brazil: rationale and concerns related to reservoir control. Rev Saude Publica 2014; 48(5): 851-856. PMid:25372177. http://dx.doi.org/10.1590/S0034-8910.2014048005615.

Word Health Organization - WHO. Leishmaniasis: burden and distribution [online]. Genebra: WHO; 2013 [cited 2013 Nov 20]. Available from: http://www.who.int/leishmaniasis/burden/en/ 